\title{
PENGARUH KUALITAS PEMBERITAAN TERHADAP TINGKAT PENGUTIPAN BERITA DI MEDIA MASSA LAMPUNG PADA PERUM LKBN ANTARA BIRO PROVINSI LAMPUNG
}

\author{
Sodirin $^{(1)}$, Endang Yuliyana ${ }^{(2)}$ \\ Fakultas Ekonomi Universitas Sang Bumi Ruwa Jurai \\ sodirin@fe.saburai.ac.id, endang.yuliyana@gmail.com
}

\begin{abstract}
Abstrak. Pada era globalisasi saat ini, berita menjadi hal mutlak yang tidak lepas dari kebutuhan masyarakat. Sejalan dengan itu kualitas pemberitaan tentu menjadi acuan atau patokan bagi masyarakat dan para pengambil kebijakan dalam menentukan sikap. Kualitas berita yang disiarkan pada masyarakat sangat bergantung pada nilai berita. Selain sebagai sumber informasi dan hiburan, berita juga dapat dikutip sesuai dengan bidang keilmuan. Berita yang faktual, relevan dan terpercaya dapat digunakan sebagai kajian keilmuan dan dikutip dalam studi kasus atau pengujian teori - teori tertentu. Semakin berkualitas berita yang dibuat semakin besar pula tingkat pengutipannya. Penelitian ini bersifat kuantitatif yang menggunakan metode penelitian deskriptif dengan pendekatan korelasional. Dari penelitian yang telah dilakukan, peneliti mendapatkan hasil pengaruh kualitas pemberitaan terhadap tingkat pengutipan berita di media massa Lampung studi pada Perum LKBN ANTARA Biro Provinsi Lampung. diketahui bahwa didapat nilai chi square kualitas pemberitaan (variabel x) sebesar 8,000 pada standart df $16=26,296$ dapat disimpulkan $8,000<26,296$. Sedangkan pada tingkat pengutipan (variabel y) chi square 9,286 pada standar df $17=$ 27,587 dapat disimpulkan 9,286 $<27,587$ n 28 dengan $\alpha 5 \%$ adalah 0,653 . Terlihat bahwa nilai $\mathrm{x} 2<\mathrm{df}$ dan nilai chi square selalu positif. Hal ini berarti ada pengaruh kualitas pemberitaan terhadap tingkat pengutipan berita di media massa Lampung studi pada Perum LKBN ANTARA Biro Provinsi Lampung.
\end{abstract}

Kata kunci: Berita, Kualitas, Pemberitaan, Pengutipan.

\section{PENDAHULUAN}

Informasi merupakan kebutuhan yang tidak lepas dari kehidupan manusia, dari zaman prasejarah hingga saat ini. Perkembangan peradaban manusia diiringi dengan perkembangan cara penyampaian informasi (yang selanjutnya dikenal dengan istilah teknologi informasi), mulai dari gambar-gambar yang tak bermakna di dinding- dinding gua, peletakan tonggak sejarah dalam bentuk prasasti, sampai diperkenalkannya dunia arus informasi yang dikenal dengan nama internet.

Pada awalnya teknologi informasi mulai dikembangkan manusia pada masa pra-sejarah. Pada masa ini berfungsi sebagai sistem untuk pengenalan bentukbentuk yang mereka kenal. Mereka menggambarkan informasi yang mereka dapatkan pada dinding-dinding gua, tentang berburu dan binatang buruannya. Pada masa ini mereka mulai melakukan pengidentifikasian benda-benda yang ada dilingkungan mereka tinggal dan mewakilinya dengan bentuk-bentuk yang kemudian mereka lukis pada dinding gua tempat mereka tinggal, karena kemampuan mereka dalam berbahasa hanya berkisar pada bentuk suara dengusan dan isyarat tangan sebagai bentuk awal komunikasi mereka pada masa ini.

Seiring berjalannya waktu, perkembangan teknologi informasi juga semakin tumbuh pesat. Ditemukannya bahasa, kalimat, huruf dan kertas menjadi awal dari perkembangan teknologi informasi. Hingga saat ini perkembangan informasi melalui media-media pemberitaan mutlak diperlukan bagi seluruh 
kalangan masyarakat. Perkembangan media cetak, elektronik, internet hingga penggunaan smartphone semakin memudahkan masyarakat mengakses beritaberita terkini secara cepat dan dinamis.

Menurut Mickhel V. Charniey, berita adalah laporan tercepat dari suatu peristiwa atau kejadian yang faktual, penting, dan menarik bagi sebagian pembaca, serta menyangkut kepentingan mereka. Sementara Willard C. Bleyer berpendapat bahwa berita adalah sesuatau yang terkini (baru) yang di pilih oleh wartawan untuk dimuat dalam surat kabar sehingga menarik minat bagi pembaca. Mickhel V. Charniey (Romli, 2009) dan Willard C. Bleyer (Romli, 2009). Sedangkan Wiliam S Maulsby menyatakan bahwa berita adalah suatu penuturan secara benar dan tidak memihak dari fakta yang punya arti penting arti penting dan baru terjadi, yang dapat menarik perhatian pembaca surat kabar yang memuat hal tersebut. Wiliam $\mathrm{S}$ Maulsby (Romli, 2009).

Berdasarkan definisi tersebut, dapat diambil kesimpulan bahwa berita adalah laporan peristiwa yang didasarkan fakta dan menarik perhatian banyak orang.Untuk memenuhi syarat berita yang baik, berita harus memuat nilai berita yang dijadikan acuan. Nilai berita dapat digunakan oleh para jurnalis, yakni para reporter dan editor, untuk memutuskan fakta yang pantas dijadikan berita dan memilih mana yang lebih baik. Kriteria mengenai nilai berita merupakan patokan berarti bagi reporter.

Berdasarkan kriteria tersebut, seorang reporter dapat dengan mudah mendeteksi mana peristiwa yang harus diliput dan dilaporkan, dan mana peristiwa yang tak perlu diliput dan harus dilupakan. Kriteria nilai berita juga sangat penting bagi para editor dalam mempertimbangkan dan memutuskan kualitas pemberitaan, mana berita terpenting dan terbaik untuk dimuat, disiarkan, atau ditayangkan melalui medianya kepada masyarakat luas.
Begitu pentingnya kutipan, para jurnalis bahkan menjuluki kutipan sebagai senjata dalam menulis. Kutipan, berupa pernyataan, terutama orang yang punya wewenang atas topik yang dipilih bakal "menghidupkan" tulisan. Tulisan menjadi tidak monoton, kering, dan searah, membuat pembaca bangun dari tidur. Kutipan muncul sebagai penegasan, ia seperti menghadirkan pihak yang dipercaya untuk memberi penjelasan pada pembaca.

Atas alasan tersebut memilih dan menempatkan kutipan secara tepat ke dalam tulisan menjadi penting. Idealnya kutipan berita didapat dari sumber - sumber terpercaya, sumber yang telah diakui relevan dan dipercaya kebenarannya. Di dalam dunia bisnis media pemberitaan seperti sekarang ini, banyak bermunculan media pemberitaan yang mengisi ruang persaingan di dunia bisnis pemberitaan.

Maka setiap instansi atau perusahaan media pemberitaan akan berpikir keras untuk dapat bersaing dan juga dapat mengungguli para pesaingnya dengan bermacam-macam cara. Salah satunya cara untuk membuat produk pemberitaannya dapat bersaing dalam menghasilkan berita yang cepat, akurat dan penting yaitu dengan berupaya mengolah dan memperbaiki produk berita yang akan dihasilkan dengan melengkapi unsur-unsur berita yang baik, teknologi yang terbaru dan meningkatkan kinerja serta insting junalistik terhadap isuisu yang berkembang di masyarakat.

ANTARA sebagai salah satu kantor berita terbesar di dunia selalu menghadirkan berita dan foto mengenai peristiwa-peristiwa penting dan mutakhir secara cepat dan lengkap ke seluruh dunia. Didukung teknologi informasi terkini, dengan memiliki jaringan komunikasi yang menjangkau berbagai pelosok tanah air dan dunia. serta memiliki biro di setiap propinsi serta perwakilan di beberapa kotamadya/kabupaten. Untuk memenuhi kebutuhan masyarakat terhadap informasi 
global, ANTARA juga menjalin kerjasama, baik secara komersial maupun nonkomersial, dengan kantor-kantor berita di seluruh dunia, seperti Australian Asosiated Press/AAP (Australia), Reuters (Inggris), Agence France de Presse/AFP (Perancis), Deutsche Presse Agentur/DPA (Jerman), Kyodo (Jepang), Berita Nasional Malaysia/Bernama (Malaysia), Xinhua (China), Committee on Institutional Cooperation/CIC (Columbia), NAMPA (Namibia) dan lain-lainnya.

Strategi pembuatan produk pemberitaan pun sangat perlu dan penting dalam meningkatkan tingkat pengutipan berita. Maka kualitas produk pemberitaan ini juga akan sangat berpengaruh dalam jumlah atau volume penjualan. Dengan kualitas produk pemberitaan yang bagus dan baik maka tingkat ketergantungan media massa di Lampung terhadap berita yang di hasilkan Perum LKBN ANTARA Biro Provinsi Lampung untuk dijadikan sebagai patokan dan pengembangan isu-isu yang berkembangpun akan meningkat atau dengan kata lain meningkat volume penjualannya.

Beberapa jenis produk dan jasa yang ditawarkan oleh Perum Lembaga Kantor Berita Nasional (LKBN) ANTARA Biro Provinsi Lampung diantaranya sebagai berikut : Warta Perundang-undangan (WPU), foto berita, VSAT (DVB-IP), TV Display ANTARA (TDA) dan layanan portal www.antaralampung.com (berita advertorial dan iklan). Warta Perundangundangan (WPU) adalah majalah yang berisi peraturan perundang-undangan terbaru yang diterbitkan DPR, Presiden, Pemerintah Pusat dan Daerah, Instansi Pemerintahan, DPRD, Gubernur, Walikota/Bupati.

Foto berita adalah produk jurnalistik yang dihasilkan oleh seorang fotografer yang memiliki nilai jual peristiwa, kecepatan, dan ketepatan pengambilan gambarnya. Suatu foto jurnalistik harus mampu mengantarkan penikmat foto menembus "dinding" yang terbatas oleh ruang dan waktu. Maksudnya, tidak hanya berhenti pada tampilan informasi saja namun membawa pembaca seakan ada saat peristiwa itu terjadi.

Berita Advertorial adalah bentuk periklanan yang disajikan dengan gaya bahasa jurnalistik. Advertorial berasal dari dua kata dalam bahasa Inggris Advertising dan Editorial. Periklanan (advertising) adalah penyajian materi secara persuasif kepada publik melalui media massa dengan tujuan untuk mempromosikan barang atau jasa. Editorial adalah pernyataan tentang opini yang merupakan sikap resmi dari redaksi.

Iklan adalah suatu pesan tentang barang/jasa (produk) yang dibuat oleh produser/pemrakarsa yang disampaikan lewat media (cetak, audio, elektronik) yang di tujukan kepada masyarakat. Tujuan iklan adalah agar masyarakat tertarik untuk membeli atau menggunakan barang atau jasa tersebut.

Berdasarkan uraian tersebut peneliti tertarik meneliti "apakah ada pengaruh kualitas berita terhadap tingkat pengutipan berita di media massa Lampung studi pada Perum LKBN ANTARA Biro Provinsi Lampung ?".

\section{KAJIAN TEORI}

\section{Pengertian Berita}

Menurut Mickhel V. Charniey mengemukakan bahwa "berita adalah laporan tercepat dari suatu peristiwa atau kejadian yang faktual, penting, dan menarik bagi sebagian pembaca, serta menyangkut kepentingan mereka" (Romli, 2009). Sementara menurut Willard C. Bleyer berita adalah sesuatau yang terkini (baru) yang di pilih oleh wartawan untuk dimuat dalam surat kabar sehingga menarik minat bagi pembaca (Romli, 2009). 
Menurut Wiliam S Maulsby berita adalah suatu penuturan secara benar dan tidak memihak dari fakta yang punya arti penting arti penting dan baru terjadi, yang dapat menarik perhatian pembaca surat kabar yang memuat hal tersebut. (Romli, 2009). Sedangkan Eric C Hepwood mengemukakan bahwa berita adalah laporan pertama dari kejadian penting dan dapat menarik perhatian umum. (Romli, 2009).

Berdasarkan definisi tersebut penulis menyimpulkan bahwa berita adalah laporan peristiwa yang didasarkan fakta dan menarik perhatian banyak orang. Suatu peristiwa atau pendapat baru akan menjadi berita bila dimuat, dipublikasikan atau disebarluaskan melalui media massar periodik dan juga untuk dapat dimuat pada media massa periodik, peristiwa dan pendapat tersebut harus memiliki persyaratan khusus yaitu memiliki bobot atau nilai berita. Persyaratan agar peristiwa dan pendapat dapat diangkat menjadi berita atau dimuat di media massa periodik jika pertistiwa dan pendapat tersebut memiliki bobot.

Di indonesia persyaratan tersebut ditambah satu lagi yaitu aman bila disiarkan atau setelah berita tesebut disebar luaskan, tidak akan menimbulkan keresahan di masyarakat. Hal ini dikarenakan Pers di Indonesia memiliki juga tanggung jawab keamanan atau securite responsibility. Pada saat ini mengalami perkembangan dan perkembangan ini disebabkan karena meningkatnya selera pembaca, mendengar dan pemirsa, di samping terjadinya perkembangan teknologi informasi pada akhir abad ke 20 ini.

\section{Nilai Berita}

Nilai berita (News Value) merupakan acuan yang dapat digunakan oleh para jurnalis, yakni para reporter dan editor, untuk memutuskan fakta yang pantas dijadikan berita dan memilih mana yang lebih baik.

Kriteria mengenai nilai berita merupakan patokan berarti bagi reporter. Dengan kriteria tersebut, seorang reporter dapat dengan mudah mendeteksi mana peristiwa yang harus diliput dan dilaporkan, dan mana peristiwa yang tak perlu diliput dan harus dilupakan. Kriteria nilai berita juga sangat penting bagi para editor dalam mempertimbangkan dan memutuskan, mana berita terpenting dan terbaik untuk dimuat, disiarkan, atau ditayangkan melalui medianya kepada masyarakat luas.

Kriteria umum nilai berita, menurut Brian S. Brooks, George Kennedy, Darly R. Moen, dan Don Ranly dalam News Reporting and Editing (1980), menunjukkan kepada sembilan hal mengenai nilai berita. Beberapa pakar lain menyebutkan, ketertarikan manusiawi (human interest) dan seks (sex) dalam segala dimensi dan manifestasinya, juga termasuk ke dalam kriteria umum nilai berita yang harus diperhatikan dengan seksama oleh para reporter dan editor media massa. (Sumadiria, 2005).

\section{Definisi Kualitas Jasa}

Jasa adalah setiap tindakan atau kegiatan yang ditawarkan oleh suatu pihak kepada pihak lain, yang pada dasarnya tidak terwujud dan tidak mengakibatkan kepemilikan apapun. Produksinya dapat dikaitkan atau tidak dengan suatu produk fisik (Kotler, 2005). Jasa adalah produk yang tidak dapat dilihat yang kita beli dan gunakan tetapi tidak pernah memiliki. (Solomon, 2003).

Jasa mencakup semua aktivitas ekonomi yang hasilnya bukanlah produk atau konstruksi fisik, yang secara umum konsumsi dan produksinya dilakukan pada saat bersamaan, dan nilai tambah yang diberikannya dalam bentuk (kenyamanan, hiburan, kecepatan, dan kesehatan) yang 
secara prinsip tidak berwujud pada pembeli pertamanya (Zeithaml, 2003).

Dengan demikian dapat dikemukakan bahwa jasa merupakan suatu tindakan atau aktivitas yang ditawarkan pada pihak lain dan tidak berwujud tetapi bisa dinikmati manfaatnya. Kualitas jasa sering didefinisikan sebagai usaha pemenuhan dari keinginan pelanggan serta ketepatan penyampaian jasa dalam rangka memenuhi harapan pelanggan. Menurut Wyckof dalam Tjiptono berpendapat bahwa Kualitas jasa merupakan tingkat keunggulan (exellence) yang diharapkan dalam pengendalian atas keunggulan tersebut untuk memenuhi keinginan pelanggan. Wyckof dalam Tjiptono (2005).

Dengan kata lain, terdapat dua faktor utama yang mempengaruhi kualitas jasa yakni, jasa yang diharapkan (expected service) dan jasa yang dipersepsikan (perceived service). Bila jasa yang diterima atau dirasakan (perceived service) sesuai dengan yang diharapkan (exspected service), maka kualitas jasa dipersepsikan baik dan memuaskan. Jika jasa yang diterima melebihi harapan pelanggan, maka kualitas jasa dipersepsikan sebagai kualitas jasa yang ideal. Akan tetapi bila jasa yang diterima lebih rendah daripada yang diharapkan, maka kualitas jasa sangat bergantung pada kemampuan penyedia jasa menyediakan jasa kepada konsumen secara continue dan konsisten.

\section{Pengertian Kutipan}

Menurut Azahari, "kutipan merupakan bagian dari pernyataan, pendapat, buah pikiran, definisi, rumusan atau penelitian dari penulis lain, atau penulis sendiri yang telah (menurut penulis kata telah harus dihilangkan) terdokumentasi, serta dikutip untuk dibahas dan ditelaah berkaitan dengan materi penulisan". (Alam, Agus Haris Purnama, 2005). Batasan di atas tidak hanya memaparkan hakikat kutipan, tetapi juga menjelaskan kepentingan mengutip, yakni untuk dibahas dan ditelaah. Hal ini mengandung pengertian bahwa pengutipan memiliki tujuan tertentu.

Kutipan juga merupakan suatu gagasan, ide, pendapat yang diambil dari berbagai sumber. Proses pengambilan gagasan itu disebut mengutip. Gagasan itu bisa diambil dari kamus, ensiklopedi, artikel, laporan, buku, koran, majalah, internet, dan lain sebagainya.

\section{METODE PENELITIAN}

\section{Objek Penelitian}

Objek peneltiannya yaitu Perum LKBN ANTARA Biro Provinsi Lampung, yang beralamat di Jl. Abdi Negara No. 2 Kelurahan Gulak Galik, Kecamatan Telukbetung Utara, Kota Bandarlampung, Provinsi Lampung, penelitian ini dilaksanakan dari bulan Juli sampai dengan bulan Agustus 2016.

\section{Metode dan Teknik Pengumpulan Data}

Dalam penelitian ini, peneliti menggunakan penelitian yang berdasarkan hubungan antara variabel pada obyek yang diteliti dengan tujuan untuk mengetahui hubungan antara dua variabel tersebut yang mempunyai hubungan kausal (sebabakibat) dengan menggunakan survey /kuisioner.

Menurut Sugiyono, variabel penelitian dapat dirumuskan sebagai berikut : "suatu atribut atau sifat atau nilai dari orang, obyek atau kegiatan yang mempunyai variasi tertentu yang ditetapkan oleh peneliti untuk dipelajari dan kemudian ditarik kesimpulannya”. Sugiyono (2015).

Penelitian ini bersifat kuantitatif yang menggunakan metode penelitian deskriptif dengan pendekatan korelasional. "Tujuan penelitian korelasional adalah untuk mengetahui pengaruh antara variabel bebas 
dengan variabel terikat". Iskandar, 2008. Penggunaan penelitian korelasi dalam penelitian ini dimaksudkan untuk menjelaskan hubungan antara variabel bebas dan variabel terikat.

Dalam penelitian ini jawaban kuisioner akan diberikan penilaian sebagai berikut :

1. Jawaban SS (Sangat Setuju) diberi skor 5

2. Jawaban S (Setuju) diberi skor 4

3. Jawaban RR (Ragu-ragu) diberi skor 3

4. Jawaban TS (Tidak Setuju) diberi skor 2

5. Jawaban STS (Sangat Tidak Setuju) diberi skor 1 .

\section{Sampel dan Populasi}

Menurut Sugiyono, sampel merupakan: "Bagian dari jumlah karakteristik yang dimiliki oleh populasi tersebut. Bila populasi besar dan peneliti tidak mungkin mempelajari semua yang ada pada populasi itu, misalnya karena keterbatasan dana, tenaga dan waktu, maka peneliti dapat menggunakan sampel yang diambil dari populasi itu. Sugiyono, (2015). Untuk itu sampel yang diambil dari populasi harus benar-benar refresentatif (mewakili) produk pemberitaan Perum LKBN ANTARA Biro Provinsi Lampung pada bulan Januari s/d Desember 2015 sebanyak 28 media massa dan elektronik. Dalam pengambilan sampel penelitian ini peneliti menggunakan teknik sampel random sampling, dimana teknik pengambilan sampel memberikan peluang yang sama kepada seluruh anggota populasi untuk dipilih sebagai anggota sampel.

\section{Metode Analisis Data}

Untuk pengolahan data dalam bentuk tabulasi hasil jawaban responden kemudian dilakukan analisis data melalui metode analisis secara kualitatif dan analisa kuantitatif.
Analisis kualitatif merupakan analisis yang dinyatakan dalam bentuk uraian dan didasarkan pada data yang telah ada. Data kualitatif merupakan data berupa informasi yang kemudian dikaitkan dengan data lainnya sehingga memunculkan suatu kebenaran.

Analisis kuantitatif yang dilakukan berdasarkan data primer yang diperoleh dari penyebaran instrument (daftar pertanyaan) kepada sampel, dan untuk mengetahui pengaruh dari variabel bebas (independent variable) terhadap variabel terikat (dependent variable).

Persamaan Regresi Linear Sederhana menentukan persamaan regresi linear sederhana untuk X :

$$
Y=a+b X+e
$$

Keterangan:

$$
\begin{aligned}
& \mathrm{Y}=\text { Tingkat pengutipan berita } \\
& \mathrm{a}=\text { Konstanta } \\
& \mathrm{b}=\text { Koefisien regresi } \mathrm{X} \\
& \mathrm{X}=\text { Kualitas pemberitaan } \\
& \mathrm{e}=\text { Faktor kesalahan }
\end{aligned}
$$

Untuk mengetahui besarnya pengaruh, penghitungan koefisien korelasi tersebut kemudian dilanjutkan dengan Rumus Koefisien Determinasi atau Koefisien Penentu (KP):

$$
K P=(r)^{2} x 100 \%
$$

Untuk menguji secara hipotesis secara parsial digunakan Uji t dengan rumus :

$$
t_{\text {hitung }}=\frac{r \sqrt{N-2}}{\sqrt{1-r^{2}}}
$$

Keterangan:

$$
\begin{array}{ll}
\mathrm{t}_{\text {hitung }} & =\text { Nilai } \mathrm{t} \\
\mathrm{r} & =\text { Koefisien Korelasi } \\
\mathrm{N} & =\text { Jumlah responden }
\end{array}
$$


Kriteria untuk Uji $\mathrm{t}$ adalah sebagai berikut :

a) Jika $t_{\text {hitung }}>t_{\text {tabel }}$ maka Ha diterima dan Ho ditolak.

b) Jika $t_{\text {hitung }} \leq \mathrm{t}_{\text {tabel }}$ maka Ha ditolak dan Ho diterima.

\section{HASIL DAN PEMBAHASAN}

\section{Uji Validitas}

Hasil analisis butir pernyataan validitas instrumen kualitas pemberitaan dari 20 butir pernyataan diperoleh 17 butir pernyataan yang valid dan 3 butir pernyataan yang di drop. Dari 17 butir penyataan yang valid adalah butir pernyataan nomor $1,2,3,4,5,6,7,8,9$, $11,13,14,15,16,17,18,20$. Sedangkan 3 butir pernyataan yang di drop adalah butir pernyataan nomor 10,12, 13 . Hasil perhitungan reliabilitas 17 butir pernyataan instrumen kualitas pemberitaan diperoleh nilai adalah 0,799 .

Hasil analisis butir pernyataan validitas instrumen kualitas pemberitaan dari 20 butir pernyataan diperoleh 18 butir pernyataan yang valid dan 2 butir pernyataan yang di drop. Dari 18 butir penyataan yang valid adalah butir pernyataan nomor $1,2,3,5,6,7,8,9,11$, $12,13,14,15,16,17,18,19,20$. Sedangkan 2 butir pernyataan yang di drop adalah butir pernyataan nomor 4,10 . Hasil perhitungan reliabilitas 18 butir pernyataan instrumen kualitas pemberitaan diperoleh nilai adalah 0,803 .

\section{Uji Reliabilitas Data}

Uji reliabilitas instrumen menggunakan rumus Cronbach Alpha $(\alpha)$ untuk masing-masing variabel adalah lebih besar dari 0,60. Demikian dapat disimpulkan bahwa item-item untuk masing-masing variabel adalah reliabel. Nilai reliabilitas konsistensi internal ditunjukkan dalam tabel diatas, untuk koefisien Alpha Cronbach dinyatakan reliabel karena lebih besar dari 0,60. Dengan demikian item pengukuran pada masing-masing indikator dalam variabelvariabel penelitian dinyatakan reliabel dan selanjutnya dapat digunakan dalam penelitan.

\section{Analisis Kuantitatif}

Berdasarkan data pengaruh kualitas pemberitaan (variabel $\mathrm{x}$ ) chi square 8,000 pada standard df $16=26,296$ dapat diketahui 8,000 < 26,296 sedangkan pada tingak pengutipan (variabel y) chi square 9,286 pada standar df $=17=27,587$ dapat disimpulkan 9,286<27,587 n 28 dengan $\alpha$ $5 \%$ adalah 0,653 . Terlihat bahwa nilai $\mathrm{x} 2<$ df dan nilai chi square selalu positif.

Berdasarkan pengujian diperoleh nilai Sig. $=0,276$ yang berarti $>$ kriteria signifikan $(0,05)$, dengan demikian model persamaan regresi berdasarkan data penelitian adalah signifikan artinya, model regresi linier memenuhi kriteria linieritas.

Persamaan regresi yang diperoleh dengan koefisien konstanta dan koefisien variabel yang ada di kolom Unstandardized Coefficients B. Berdasarkan model persamaan regresi adalah $\mathrm{Y}=-3,108+$ 0,963X. Konstanta sebesar $-3,108$ artinya pengaruh kualitas pemberitaan $(\mathrm{X})$ nilainya adalah 0 , maka tingkat pengutipan berita (Y) nilainya negatif yaitu sebesar 3,108. Koefisien regresi variabel kualitas pemberitaan (X) sebesar 0,963; artinya jika pengaruh kualitas pemberitaan mengalami tingkat kenaikan sebesar $1 \%$ maka tingkat pengutipan berita (Y) akan mengalami peningkatan sebesar 0,963. Koefisien bernilai positif artinya terjadi hubungan positif antara pengaruh kualitas pemberitaan terhadap tingkat pengutipan berita di media massa Lampung. Jadi dapat disimpulkan bahwa ha diterima dan ho ditolak atau ha ada pengaruh kulaitas 
pemberitaan terhadap tingkat pengutipan berita di media massa Lampung studi pada Perum LKBN ANTARA Biro Provinsi Lampung.

Dari penelitian yang telah dilakukan, peneliti mendapatkan hasil pengaruh kualitas pemberitaan terhadap tingkat pengutipan berita di media massa Lampung studi pada Perum LKBN ANTARA Biro Provinsi Lampung. Diketahui bahwa didapat nilai uji regresi linear sederhana koefisien regresi variabel kulaitas pemberitaan (X) sebesar 0,963 artinya jika pengaruh kualitas pemberitaan mengalami tingkat kenaikan sebesar $1 \%$ maka tingkat pengutipan berita (Y) akan mengalami peningkatan sebesar 0,963 . Hal ini berarti ada pengaruh kualitas pemberitaan terhadap tingkat pengutipan berita di media massa Lampung studi pada Perum LKBN ANTARA Biro Provinsi Lampung.

Suatu peristiwa atau pendapat baru akan menjadi berita bila dimuat, dipublikasikan atau disebarluaskan melalui media massar periodik dan juga untuk dapat dimuat pada media massa periodik, peristiwa dan pendapat tersebut harus memiliki persyaratan khusus yaitu memiliki bobot atau nilai berita. Menurut Azahari, "kutipan merupakan bagian dari pernyataan, pendapat, buah pikiran, definisi, rumusan atau penelitian dari penulis lain, atau penulis sendiri yang telah (menurut penulis kata telah harus dihilangkan) terdokumentasi, serta dikutip untuk dibahas dan ditelaah berkaitan dengan materi penulisan" (Haris Purnama, 2005).

Batasan di atas tidak hanya memaparkan hakikat kutipan, tetapi juga menjelaskan kepentingan mengutip, yakni untuk dibahas dan ditelaah. Hal ini mengandung pengertian bahwa pengutipan memiliki tujuan tertentu. Kutipan juga merupakan suatu gagasan, ide, pendapat yang diambil dari berbagai sumber. Proses pengambilan gagasan itu disebut mengutip.
Gagasan itu bisa diambil dari kamus, ensiklopedi, artikel, laporan, buku, koran, majalah, internet, dan lain sebagainya.

Dari hasil penelitian yang menunjukan bahwa pengaruh tingkat pengutipan berita di media massa Lampung dalam mengutip berita kita diperkenankan menghilangkan bagian-bagian kutipan dengan syarat bahwa penghilangan bagian itu tidak menyebabkan perubahan makna atau arti yang terkandung dalam sumber kutipan kita. Maka dapat diambil kesimpulan bahwa dalam mengutip berita terdapat prinsip- prinsip yang harus diperhatikan.

Apabila dalam mengutip sebuah karya atau tulisan yang ada salah ejaan dari sumber kutipan kita, maka sebaiknya kita biarkan saja apa adanya seperti sumber yang kita ambil tersebut. Kita sebagai pengutip tidak diperbolehkan membenarkan kata ataupun kalimat yang salah dari sumber kutipan kita.

Dalam kutipan kita diperkenankan menghilangkan bagian-bagian kutipan dengan syarat bahwa penghilangan bagian itu tidak menyebabkan perubahan makna atau arti yang terkandung dalam sumber kutipan kita. Caranya :

1. Menghilangkan bagian kutipan yang kurang dari satu alinea. Bagian yang dihilangkan diganti dengan tiga titik berspasi.

2. Menghilangkan bagian kutipan yang kurang dari satu alinea. Bagian yang dihilangkan diganti dengan tiga titik berspasi sepanjang garis (dari margin kiri sampai margin kanan).

\section{KESIMPULAN DAN SARAN}

\section{Kesimpulan}

Berdasarkan hasil penelitian dapat disimpulkan bahwa hasil pengaruh kualitas pemberitaan terhadap tingkat pengutipan berita di media massa Lampung studi pada 
Perum LKBN ANTARA Biro Provinsi Lampung. diketahui bahwa didapat nilai chi square kualitas pemberitaan (variabel $\mathrm{x}$ ) sebesar 8,000 pada standart df $16=26,296$ dapat disimpulkan $8,000<26,296$. Sedangkan pada tingkat pengutipan (variabel y) chi square 9,286 pada standar df $17=27,587$ dapat disimpulkan 9,286< 27,587 n 28 dengan $\alpha 5 \%$ adalah 0,653. Terlihat bahwa nilai $\mathrm{x} 2<\mathrm{df}$ dan nilai chi square selalu positif. Hal ini berarti ada pengaruh kualitas pemberitaan terhadap tingkat pengutipan berita di media massa Lampung studi pada Perum LKBN ANTARA Biro Provinsi Lampung.

\section{Saran}

Adapun saran yang dapat diberikan adalah:

1. Dalam mengutip berita terdapat prinsip-prinsip yang harus diperhatikan yakni apabila dalam mengutip sebuah karya atau tulisan yang ada salah ejaan dari sumber kutipan kita, maka sebaiknya kita biarkan saja apa adanya seperti sumber yang kita ambil tersebut. Kita sebagai pengutip tidak diperbolehkan membenarkan kata ataupun kalimat yang salah dari sumber kutipan kita.

2. Dalam kutipan kita diperkenankan menghilangkan bagian-bagian kutipan dengan syarat bahwa penghilangan bagian itu tidak menyebabkan perubahan makna atau arti yang terkandung dalam sumber kutipan kita. Caranya:

a. Menghilangkan bagian kutipan yang kurang dari satu alinea. Bagian yang dihilangkan diganti dengan tiga titik berspasi.

b. Menghilangkan bagian kutipan yang kurang dari satu alinea. Bagian yang dihilangkan diganti dengan tiga titik berspasi sepanjang garis (dari margin kiri sampai margin kanan).

\section{DAFTAR PUSTAKA}

Alam, Agus Haris Purnama. 2005. Konsep Penulisan Laporan Ilmiah. (Format dan Gaya). Bandung: YIM Press.

Arikunto, Suharsimi. 2006. Pedoman Penulisan Ilmiah Skripsi dan Tesis. Jakarta: Oryza.

AS, Haris Sumaridia. 2005. Jurnalistik Indonesia, Menulis Berita dan Feature, Panduan Praktis Jurnalis Profesional. Bandung: Remaja Rosdakarya.

Djaali, 2008. Skala Likert. Jakarta: Pustaka Utama.

Indriantoro, Nur dan Supomo, Bambang. 2007. Metode Penelitian Bisnis. Bandung: CV ALFABETA.

Iskandar, 2008. Metodologi Penelitian, Pendidikan dan Sosial (Kuantitatif dan Kualitatif). Jakarta: GP Press.

Kotler, Philip. 2005. Manajamen Pemasaran, Jilid 1 dan 2. Jakarta: PT. Indeks. Kelompok Gramedia.

LKBN Antara, Perum 2014. Annual Report, Jakarta. ANTARA Publishing Unit.

Romli. Asep S.M. 2009. Jurnalistik Praktis, Bandung: Remaja Rosdakarya.

Riduwan. 2005. Belajar Mudah Penelitian Untuk Guru, Karyawan dan Peneliti Pemula. Bandung: Alfabeta.

Salomon, R. Michael dan Stuart, W. Elnora. 2003. Marketing Real People, Real 
Choices, International Edition. New Jersey: Prentice Hall.

Sugiyono. 2015. Metode Penelitian Pendidikan (Pendekatan Kuantitatif, Kualitatif, dan R\&D). Bandung: Alfabeta.

Tjiptono, Fandy. 2005. Pemasaran Jasa. Edisi pertama. Malang: Bayu Media Publishing.

Uma Sekaran. 2006. Metode Penelitian Untuk Bisnis. Jakarta: Salemba Empat.

Umar, Husein. 2007. Metode Penelitian Untuk Skripsi Dan Tesis Bisnis. Jakarta: PT. Raja Grafindo Persada. 